\title{
Subglacial hydrological control on flow of an Antarctic Peninsula palaeo-ice stream
}

\author{
Robert D. Larter ${ }^{1}$, Kelly A. Hogan ${ }^{1}$, Claus-Dieter Hillenbrand ${ }^{1}$, James A. Smith ${ }^{1}$, Christine L. Batchelor ${ }^{2}$, \\ Matthieu Cartigny ${ }^{3}$, Alex J. Tate ${ }^{1}$, James D. Kirkham ${ }^{1,2}$, Zoë A. Roseby ${ }^{1,4}$, Gerhard Kuhn ${ }^{5}$, Alastair G. C. Graham ${ }^{6}$, \\ and Julian A. Dowdeswell ${ }^{2}$ \\ ${ }^{1}$ British Antarctic Survey, Madingley Road, High Cross, Cambridge CB3 0ET, UK \\ ${ }^{2}$ Scott Polar Research Institute, University of Cambridge, Lensfield Road, Cambridge CB2 1ER, UK \\ ${ }^{3}$ Department of Geography, South Road, Durham University, Durham DH1 3LE, UK \\ ${ }^{4}$ Ocean and Earth Science, National Oceanography Centre, University of Southampton Waterfront Campus, European Way, \\ Southampton SO14 3ZH, UK \\ ${ }^{5}$ Alfred Wegener Institute, Helmholtz Centre for Polar and Marine Research, 27568 Bremerhaven, Germany \\ ${ }^{6}$ College of Life and Environmental Sciences, University of Exeter, Rennes Drive, Exeter EX4 4RJ, UK
}

Correspondence: Robert D. Larter (rdla@bas.ac.uk)

Received: 10 December 2018 - Discussion started: 30 January 2019

Revised: 23 April 2019 - Accepted: 29 April 2019 - Published: 5 June 2019

\begin{abstract}
Basal hydrological systems play an important role in controlling the dynamic behaviour of ice streams. Data showing their morphology and relationship to geological substrates beneath modern ice streams are, however, sparse and difficult to collect. We present new multibeam bathymetry data that make the Anvers-Hugo Trough west of the Antarctic Peninsula the most completely surveyed palaeo-ice stream pathway in Antarctica. The data reveal a diverse range of landforms, including streamlined features where there was fast flow in the palaeo-ice stream, channels eroded by flow of subglacial water, and compelling evidence of palaeo-ice stream shear margin locations. We interpret landforms as indicating that subglacial water availability played an important role in facilitating ice stream flow and controlling shear margin positions. Water was likely supplied to the ice stream bed episodically as a result of outbursts from a subglacial lake located in the Palmer Deep basin on the inner continental shelf. These interpretations have implications for controls on the onset of fast ice flow, the dynamic behaviour of palaeo-ice streams on the Antarctic continental shelf, and potentially also for behaviour of modern ice streams.
\end{abstract}

\section{Introduction}

There is growing evidence that basal hydrology is a critical factor controlling the dynamic behaviour of ice streams (Bell, 2008; Christianson et al., 2014; Christoffersen et al., 2014), which account for most of the mass loss from large ice sheets. Understanding ice stream dynamics, including basal hydrology, is thus essential for quantifying ice sheet contributions to sea level change. Subglacial lakes and areas of elevated geothermal heat flux have been discovered in the onset regions of several large ice streams (Fahnestock et al., 2001; Bell et al., 2007; Stearns et al., 2008). Obtaining high resolution topographic data from modern ice stream beds that can reveal features associated with subglacial water flow is, however, logistically difficult and time consuming (e.g. Christianson et al., 2012). In contrast, modern ship-mounted sonar systems can be used to obtain such data efficiently over extensive areas of former ice stream beds on continental shelves that ice has retreated from since the Last Glacial Maximum (LGM; 23-19 ka cal BP).

Knowledge and interpretations of submarine glacial landforms have advanced rapidly over the past 2 decades (Dowdeswell et al., 2016). For example, it is now recognized that elongated drumlins and mega-scale glacial lineations (MSGLs) are signatures of past streaming ice flow on wet-based, mainly sedimentary beds, and that elonga- 
tion generally increases with increasingly fast past flow rates (Stokes and Clark, 1999; Ó Cofaigh et al., 2002). The degree of preservation of fields of MSGLs and the extent to which they are overprinted by grounding zone wedges and transverse moraines provide an indication of the rapidity of past grounding line retreat (Ó Cofaigh et al., 2008). "Hillhole pairs" and sediment rafts are recognized as features formed by glaciotectonic processes beneath cold, dry-based ice (Evans et al., 2006; Klages et al., 2015). Erosion of meandering or anastomosing seabed channels and tunnel valleys with reversals of gradient along their length requires a hydrological pressure gradient that indicates they could only have formed beneath grounded ice (Ó Cofaigh et al., 2002; Nitsche et al., 2013). Simple hydrological pressure calculations indicate that a gentle ice surface gradient produces a pressure gradient at the bed that will drive water up an opposing bed slope nearly 10 times as steep.

Modern ice sheet observations have revealed increases in ice flow rates over timescales of days to years in response to Antarctic subglacial drainage events (Stearns et al., 2008; Siegfried et al., 2016). Responses of glaciers in southwest Greenland to seasonal drainage of supraglacial meltwater to the bed, however, show that the mode of subglacial drainage is important, as a slowdown of glacier flow above a certain run-off threshold has been interpreted to correspond to a switch to more efficient, channelized drainage (Sundal et al., 2011).

Here we present extensive new multibeam bathymetry data from the Anvers-Hugo Trough (AHT) west of the Antarctic Peninsula (Fig. 1). We interpret bedforms revealed by these data as evidence of a basal hydrological system that influenced the flow and lateral extent of the palaeo-ice stream and was fed by a subglacial lake in a deep basin on the inner continental shelf. We use heritage multichannel seismic (MCS) and deep-tow boomer (DTB) data to constrain the nature of substrates beneath the LGM deposits and their potential influence on the basal hydrological system and sediment supply.

\subsection{Glacial history and setting}

Drilling results and seismic reflection profiles indicate that the Antarctic Peninsula Ice Sheet has advanced to its western continental shelf edge many times since the late Miocene (Larter et al., 1997; Barker and Camerlenghi, 2002). Through repeated glaciations the ice sheet has eroded and overdeepened the inner shelf, extended the outer shelf through progradation, and delivered large volumes of sediment to the deep ocean (Barker and Camerlenghi, 2002; Bart and Iwai, 2012; Hernández-Molina et al., 2017). The AHT, a $140 \mathrm{~km}$ long by $50 \mathrm{~km}$ wide cross-shelf trough (Fig. 1), was a recurring ice stream pathway during glacial maxima (Larter and Cunningham, 1993; Larter and Vanneste, 1995). The most recent grounding zone advance to the shelf edge along the AHT occurred during the LGM (Pudsey et al., 1994; Heroy and
Anderson, 2005; Ó Cofaigh et al., 2014). To the southeast of the trough, the inner shelf is incised by an erosional basin, Palmer Deep (PD), that measures $26 \mathrm{~km}$ east to west and $10 \mathrm{~km}$ north to south at the $800 \mathrm{~m}$ depth contour (Domack et al., 2006; Fig. 1). PD has a maximum depth $>1400 \mathrm{~m}$, yet to both the north and south there are small islands within $12 \mathrm{~km}$ of its axis and there is a bank directly to its west that rises to $<200 \mathrm{~m}$ below sea level. Rebesco et al. (1998) and Domack et al. (2006) argued that in colder temperatures than today and with a lower sea level - e.g. at the start of Marine Isotope Stage $2(29 \mathrm{ka})$ - ice encroached towards PD from the nearby land areas and local ice caps formed on emergent platforms around the present-day islands near the basin. These authors further hypothesized that continued glacial development led to the PD basin becoming completely encircled by grounded glacial ice and to formation of an ice shelf over it, trapping a subglacial lake. Based on multibeam bathymetry data from the inner shelf, Domack et al. (2006) described channels crossing the deepest part of the sill separating the western end of PD from the AHT that are 200-500 m wide and 100-300 $\mathrm{m}$ deep and exhibit reversals in their longitudinal profiles. On the basis of these characteristics and similarities to channels in Pine Island Bay and to the Labyrinth channels in Wright Valley in the Transantarctic Mountains that had previously been interpreted as having been eroded by subglacial water flow (e.g. Lowe and Anderson, 2003; Nitsche et al., 2013; Lewis et al., 2006), Domack et al. (2006) interpreted the channels as having been eroded by outflow from a subglacial lake in PD. More recently, geochemical analysis of pore waters from sediments in one of the basins within the channel network in Pine Island Bay confirmed that it had been a subglacial lake (Kuhn et al., 2017).

\section{Methods}

\subsection{Multibeam bathymetry and acoustic sub-bottom profile data}

Extensive new data were collected on RRS James Clark Ross cruise JR284 in January 2014 using a $1^{\circ} \times 1^{\circ}$ Kongsberg EM122 system with 432 beams and a transmission frequency in the range $11.25-12.75 \mathrm{kHz}$ (Supplement Fig. S1). Beam raypaths and seabed depths were calculated in near real time using sound velocity profiles derived from conductivitytemperature-depth and expendable bathythermograph casts made during the cruise. Processing consisted of rejecting outlying values, replacing the sound velocity profile applied during acquisition with a more relevant one for some data, and gridding to isometric $30 \mathrm{~m}$ cells using a Gaussian weighted mean filter algorithm in MB-System software (Caress and Chayes, 1996; Caress et al., 2018). Pre-existing multibeam data, mostly collected on RVIB Nathaniel B. Palmer and previous cruises of RRS James Clark Ross (Anderson, 2005; Domack, 2005; Lavoie et al., 2015), and data along a few 


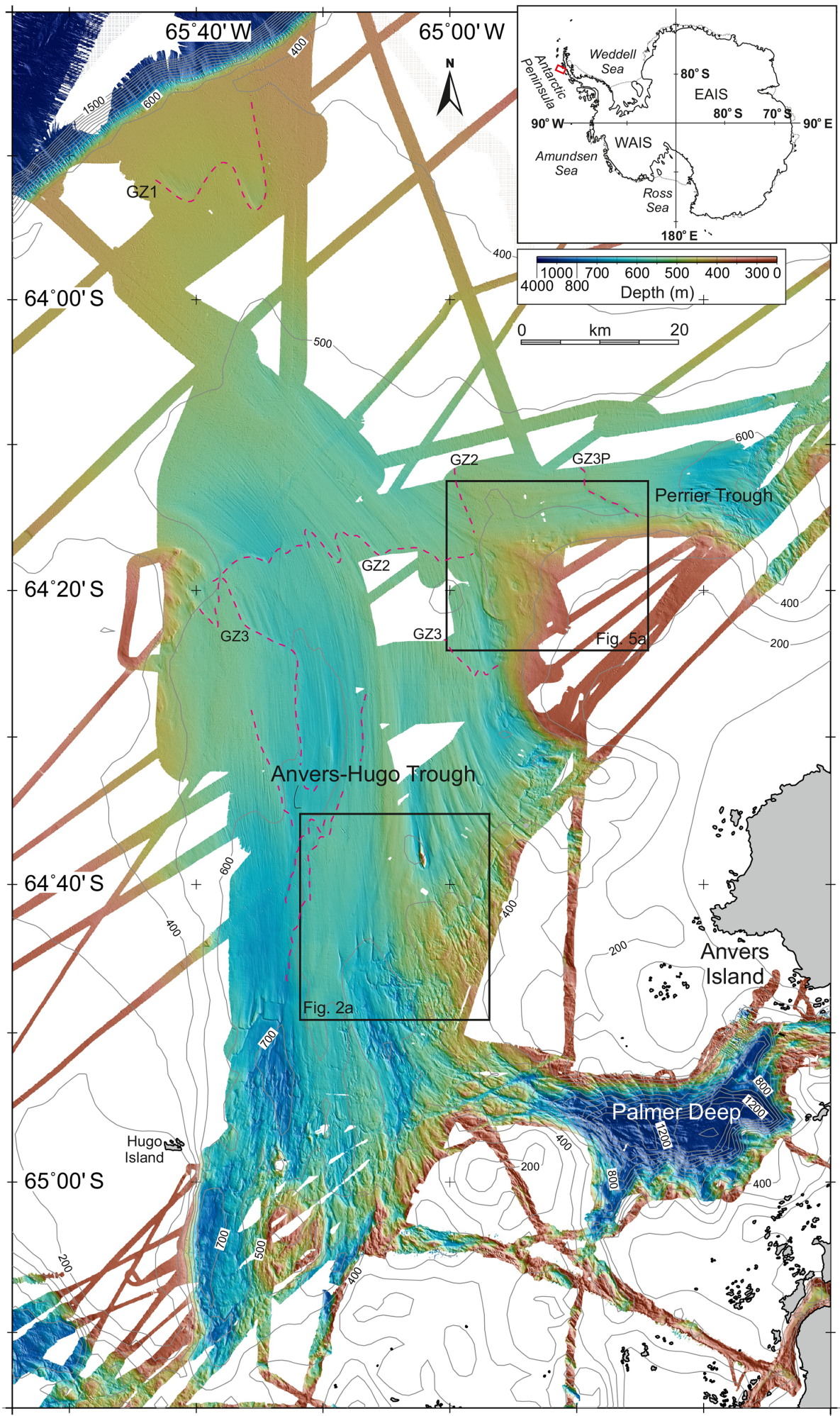

Figure 1. Multibeam bathymetry data over Anvers-Hugo Trough, Perrier Trough, and Palmer Deep. Grid-cell size $30 \mathrm{~m}$, displayed with shaded relief illumination from the northeast. Regional bathymetry contours from IBCSO v1.0 (Arndt et al., 2013). Red dashed lines mark interpreted past grounding zone positions, with the earliest ones labelled GZ1-GZ3. The grounding zone furthest upstream in Perrier Trough is labelled GZ3P, as it did not necessarily form synchronously with GZ3. Only discontinuous segments of later grounding zone positions are identified in Anvers-Hugo Trough. Black boxes show locations of Figs. 2a and 5a. The red box in the inset shows the location of the main figure. EAIS, East Antarctic Ice Sheet; WAIS, West Antarctic Ice Sheet. 
tracks collected more recently on HMS Protector using a Kongsberg EM710 system (70-100 kHz), were included in the grid (Supplement Tables S1, S2, and Fig. S1). Acoustic sub-bottom echo-sounding profiles were collected along all JR284 survey lines with a Kongsberg TOPAS PS018 parametric system using a $15 \mathrm{~ms}$ chirp transmission pulse with secondary frequencies ranging from 1.3 to $5 \mathrm{kHz}$. Vessel motion and GPS navigation data on cruise JR284 were collected using a Seatex Seapath 200 system.

\subsection{Heritage seismic reflection data}

MCS data used were collected in the 1980s on RRS Discovery cruises D154 and D172 (Larter and Cunningham, 1993; Larter et al., 1997). On D154, Line AMG845-03 was collected with a $2400 \mathrm{~m}$ long hydrophone streamer, whereas on D172 the streamer used to collect data on Line BAS878-11 was $800 \mathrm{~m}$ in length. In both cases the streamer was towed at $8-10 \mathrm{~m}$ depth and data were recorded from $50 \mathrm{~m}$ long groups with a sampling interval of $4 \mathrm{~ms}$. The seismic source consisted of four airguns with total volumes of $8.5 \mathrm{~L}$ on D154 and $15.8 \mathrm{~L}$ on D172, respectively, and data were processed to a common midpoint stack using standard procedures. Very high-resolution seismic data were collected using a Huntec DTB, towed within $100 \mathrm{~m}$ of the seabed, on RRS James Clark Ross cruise JR01 in 1992 (Larter and Vanneste, 1995; Vanneste and Larter, 1995). This system transmitted a broadband pulse with frequencies of $0.8-10 \mathrm{kHz}$ and a cycle time of $0.9 \mathrm{~s}$. Data were recorded with a $100 \mu$ s sampling interval from a $1 \mathrm{~m}$ long hydrophone trailed behind the towed vehicle. The DTB system is capable of resolving sedimentary layers $<1 \mathrm{~m}$ in thickness and also achieves very high spatial resolution due to the proximity of the source and receiver to the sea bed.

\section{Results}

\subsection{Description and interpretation of landforms and seismic/acoustic profiles}

Integration of the new multibeam bathymetry data with preexisting data provides nearly continuous coverage of the AHT from PD to beyond the continental shelf edge, with the new data spanning the full width of the trough on the middle shelf (Fig. 1). They also include coverage of the confluence with a tributary trough that joins the AHT from the east on the middle shelf. We will refer to this tributary by the informal name "Perrier Trough", as it originates offshore from Perrier Bay, Anvers Island. The data reveal extensive areas of MSGLs and drumlins, which are characteristic of ice stream beds and show the pattern of palaeo-ice flow (Stokes and Clark, 1999; King et al., 2009; Graham et al., 2009). Fields of drumlins, with elongation ratios between 2.5 and $6: 1$, occur over a broad transition zone between the rugged inner shelf and smoother mid-shelf part of the AHT, and where the AHT crosses a structural high that separates middle and outer shelf areas (Larter et al., 1997). MSGLs in the midshelf part of the AHT have elongation ratios between 12 and $17: 1$, whereas some on the outer shelf have elongation ratios up to $80: 1$. The data also confirm the occurrence of several grounding zone wedges (Fig. 1), some of which had been identified previously, indicating positions where the grounding zone paused during retreat from its LGM position (Larter and Vanneste, 1995; Vanneste and Larter, 1995; Batchelor and Dowdeswell, 2015). Here, however, we focus on two specific areas in which the landforms observed have a bearing on the role of subglacial hydrology in facilitating and controlling ice stream flow.

\subsection{Southern Anvers-Hugo Trough}

In the southern part of the AHT there is a marked alongtrough change in landforms across a line where a MCS profile (AMG845-03) shows that a mid-shelf sedimentary basin pinches out (Figs. 2a and 3), with acoustic basement cropping out to the southeast (Larter et al., 1997). The acoustic basement most likely represents Palaeozoic-Mesozoic igneous and metasedimentary rocks similar to those that crop out on the nearby islands (Storey and Garrett, 1985; Leat et al., 1995). The sedimentary strata in the basin are of unknown age, but it has previously been inferred that the youngest layers could be no younger than middle Miocene and the oldest layers may be early Tertiary or Late Cretaceous in age (Larter et al., 1997). Crescentic scours around the "upstream" ends of bathymetric highs and fields of anastomosing channels are observed in the area where the acoustic basement crops out (Fig. 2a). Among the anastomosing channels, the largest are up to $30 \mathrm{~m}$ deep and $250 \mathrm{~m}$ wide, although many are smaller (Fig. 2b).

In the axis of the AHT directly north of this zone, incised into the edge of the sedimentary basin, the new data reveal a set of northward-shoaling and narrowing valleys spaced 2-3 km apart (Fig. 2a). Individual valleys are up to $1100 \mathrm{~m}$ wide and $60 \mathrm{~m}$ deep at their southern ends (Fig. 2c), but become narrower and shallower northwards (Fig. 2c, d), ultimately petering out over a distance of $<5 \mathrm{~km}$. The slope angles along the steepest parts of the channel axes are $\sim 2^{\circ}$ (Fig. 2d). In detail, the southern part of each valley exhibits a $v$-shaped deeper section incised into a $u$-shaped upper section, the $v$-shaped sections being up to $350 \mathrm{~m}$ wide and $45 \mathrm{~m}$ deep (Fig. 2c). MSGLs start directly north of these valleys (Figs. 2a and 4) and cover most of the seabed in the trough between this point and the continental shelf edge.

Two acoustic sub-bottom profiles that run transverse to the trough about 8 and $10 \mathrm{~km}$ north of the northern tips of the valleys show that the MSGLs were formed in the surface of an acoustically transparent layer that is draped by a $4 \mathrm{~m}$ thick layer of younger sediments (Fig. 4). Where such acoustically transparent layers have been cored elsewhere on the West Antarctic shelf they have been shown to con- 

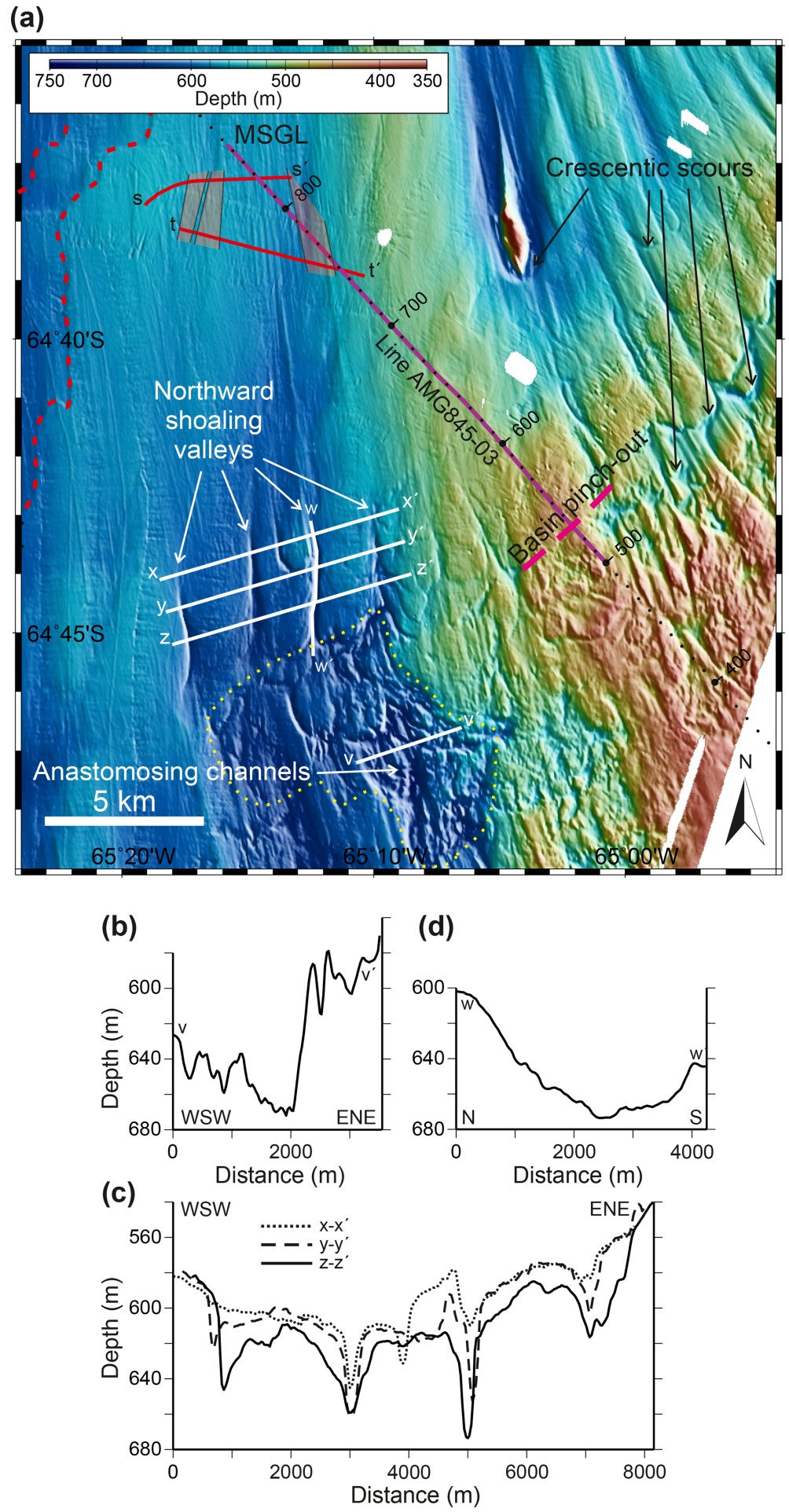

Figure 2. (a) Details of multibeam bathymetry over the boundary of the mid-shelf basin in the southern part of Anvers-Hugo Trough. Gridcell size $30 \mathrm{~m}$, displayed with shaded relief illumination from $075^{\circ}$. Dashed red lines mark interpreted former grounding zone positions. The purple line marks the location of the MCS profile in Fig. 3, with small dots at intervals of 10 shots and larger dots and annotations at 100-shot intervals. White lines mark locations of topographic profiles in (b)-(d) and solid red lines mark locations of acoustic sub-bottom profiles in Fig. 4. Semi-transparent pink-filled areas crossing the sub-bottom profiles mark the positions of the buried channels observed in the profiles and interpolated between them. The yellow dotted line outlines the approximate extent of the area of anastomosing channels. MSGL, mega-scale glacial lineations. (b) Profile across anastomosing channels. (c) Cross sections of northward-shoaling valleys. (d) Profile along the axis of one northward-shoaling valley. Locations of profiles shown in (a). 


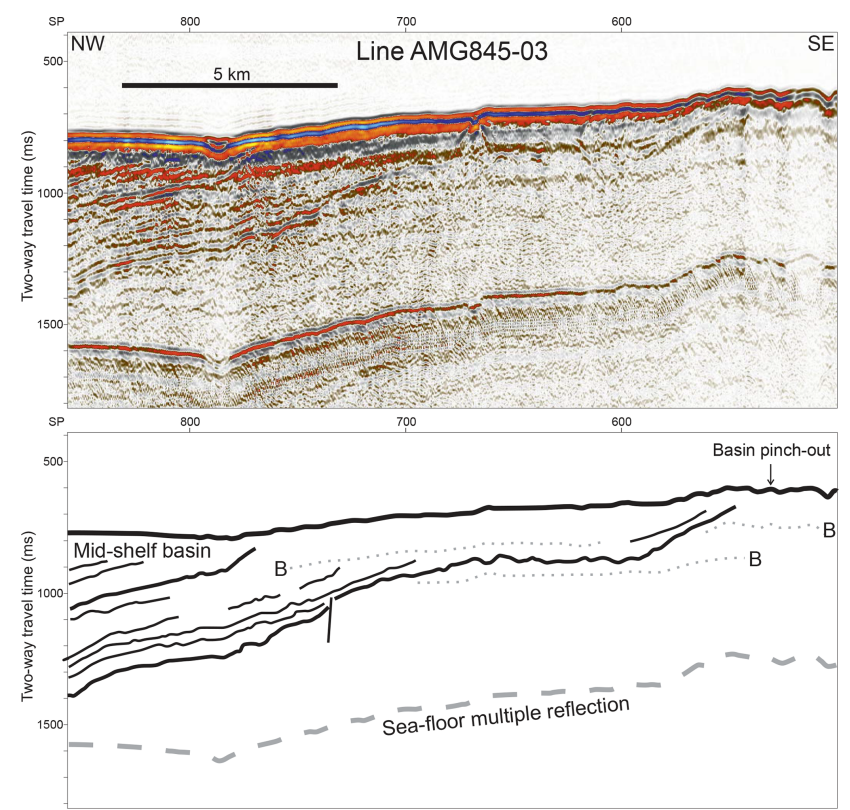

Figure 3. Part of MCS Line AMG845-03 and interpreted line drawing, showing sedimentary basin pinch out at $\sim$ SP530. Dotted grey lines labelled B on the line drawing mark prominent bubble pulse reverberations following the sea-floor reflection. Location of profile, including shot point positions, shown in Fig. 2a.

sist of relatively low shear strength, deformed till, dubbed "soft till", and the high-amplitude reflector below this layer has been shown to correlate with the top of a higher-shearstrength "stiff till" (e.g. Ó Cofaigh et al., 2005a; Reinardy et al., 2011). A homogenous, terrigenous diamicton with moderate shear strength, which was recovered in marine sediment cores from AHT, documents the presence of the soft till there (Pudsey et al., 1994; Heroy and Anderson, 2005). Each of the sub-bottom profiles shows three depressions in this high amplitude reflector that are 8-10 m deep and 400-800 $\mathrm{m}$ wide and contain an acoustically transparent fill, above which a reflector is usually observed separating the fill from the overlying soft till layer (Fig. 4).

We interpret the anastomosing channels and crescentic scours incised into the hard substrate on the inner shelf as having been eroded by subglacial water flow at times when grounded ice extended further offshore, as previous authors have interpreted similar features elsewhere (Dreimanis, 1993; Lowe and Anderson, 2003; Nitsche et al., 2013; Lewis et al., 2006; Graham and Hogan, 2016). This origin is also consistent with the interpretation that a subglacial lake was present in PD during the last glacial period, and channels incising the sill at its western end were eroded by outflow from the lake (Domack et al., 2006). Considering the scale of such features here, as well as in other areas around Antarctica, and the nature of the material they are eroded into, they probably developed progressively through multiple glacial cycles (Smith et al., 2009; Nitsche et al., 2013). The scale of the fea-
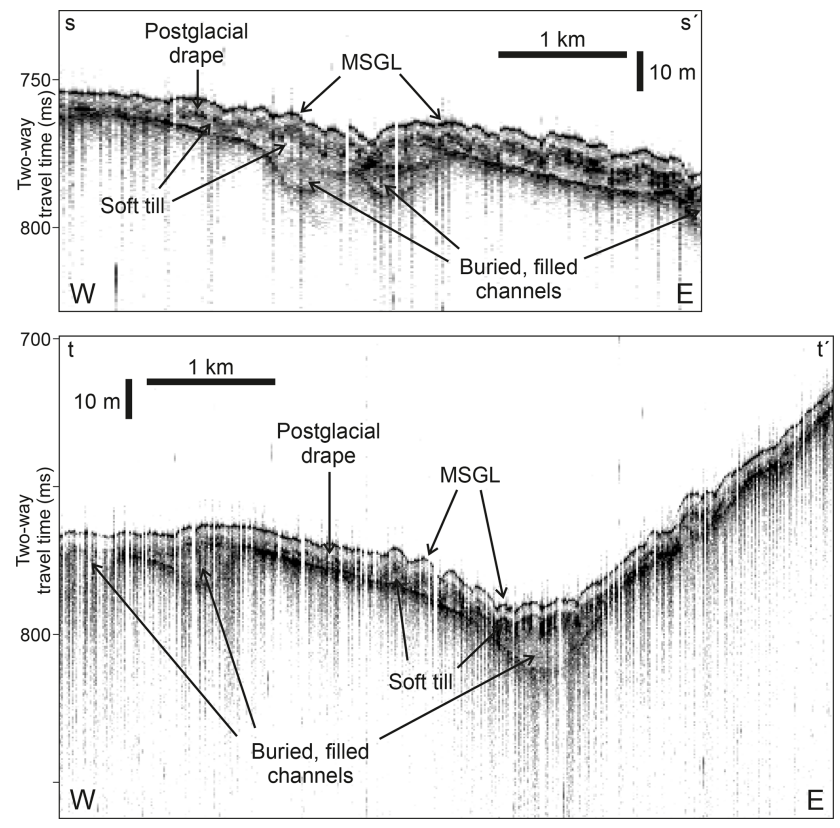

Figure 4. Acoustic sub-bottom (TOPAS) profiles from the southern part of Anvers-Hugo Trough showing buried, filled channels overlain by acoustically transparent "soft till" layer with MSGLs on its surface, which is in turn overlain by a thin drape of postglacial sediments. Locations of profiles shown in Fig. 2a.

tures also implies that water flow rates fast enough to drive erosion can only have been achieved through subglacial storage of water and episodic discharge (rather than continuous flow), even if it is assumed that the upper parts of scours and channels were filled with ice (Nitsche et al., 2013; Kirkham et al., 2019). This is, once again, consistent with the interpretation of a subglacial lake in PD, and also with a semiquantitative model that implies outbursts from trapped subglacial lakes in such settings and of these approximate dimensions are likely to occur with repeat periods of the order of a few centuries (Alley et al., 2006).

A conservative estimate for the volume of the PD subglacial lake stated by Domack et al. (2006) was $20 \mathrm{~km}^{3}$. However, the full volume of the basin deeper than the sill depth of $\sim 500 \mathrm{~m}$ is about $110 \mathrm{~km}^{3}$. If this were filled the lake would have been nearly 2 orders of magnitude greater in volume than subglacial Lake Ellsworth $\left(1.37 \mathrm{~km}^{3}\right.$; Woodward et al., 2010), but still nearly 2 orders of magnitude smaller than Lake Vostock $\left(5400 \pm 1600 \mathrm{~km}^{3}\right.$; Studinger et al., 2004). The length and width of PD are similar to Lake Engelhardt, the largest of a number of connected shallow lakes beneath the lower Mercer and Whillans ice streams, from which remotesensing data show $\sim 2 \mathrm{~km}^{3}$ of water drained between October 2003 and June 2006 (Fricker et al., 2007). However, water depth in these lakes likely rarely exceeds $10 \mathrm{~m}$ (Christianson et al., 2012), so their volumes are small compared to the potential size of lakes in deep basins such as PD. 
Considering that the northward-shoaling valleys are located in the axis of the AHT directly north of an area containing anastomosing channels and crescentic scours, we interpret them as also having been eroded by subglacial water flow. We interpret the upper $u$-shaped sections of the valleys (Fig. 2c) as having been widened by glacial erosion, implying that the valleys have been overridden by ice since they were first carved. This is consistent with the suggestion that many features eroded into bedrock on Antarctic continental shelves developed through multiple glaciations (Graham et al., 2009). Even at times when there was active water flow, ice may also have filled a large part of the $v$-shaped lower sections. Palaeo-ice flow paths indicated by streamlined bedforms show that the area in the axis of the AHT where the valleys occur lies directly down flow from the sill at the western end of PD. MSGLs directly north of the valleys indicate that there was fast ice flow in this part of the trough, likely facilitated by the soft till layer that is seen as an acoustically transparent layer in sub-bottom profiles (see Alley et al., 1986; Ó Cofaigh et al., 2005a; Reinardy et al., 2011). The coincidence of the onset of MSGLs with northward disappearance of the valleys suggests that water supplied through them was important in lubricating and dilating the till, thus reducing its shear strength and making it more prone to deform under stress. Thus we infer that the northward terminations of the valleys were associated with a transition from channelized to distributed water flow at the ice bed. The shallow, filled depressions observed in the sub-bottom profiles (Fig. 4) suggest that the valleys once continued further to the north, before their distal reaches were filled and the overlying soft till in which MSGLs are formed accumulated beneath fast-flowing ice. The sequence of units observed in the profiles could have resulted from upstream migration of the onset of sediment-lubricated streaming flow during the last glaciation.

\subsection{Confluence of Anvers-Hugo and Perrier troughs}

In the area of the confluence between AHT and Perrier Trough, an area of east-west-aligned MSGLs terminates abruptly along a line parallel to their trend on the southern flank of the Perrier Trough (Fig. 5a). The eastern limit of the area covered by MSGLs in AHT is more irregular, but lies within a band no more than $3 \mathrm{~km}$ wide on the eastern flank of the trough. Streamlined bedforms are absent from the area between the two troughs, but several steep-sided bathymetric basins up to $1500 \mathrm{~m}$ wide and $40 \mathrm{~m}$ deep are observed (Fig. 5a-c). The central parts of most basins are flat or gently dipping so that cross sections exhibit box-shaped profiles (Fig. 5b, c). A $500 \mathrm{~m}$ wide and $8 \mathrm{~m}$ high mound occurs on the northwestern side of one of the largest basins (Fig. 5c). A few of the basins span the boundary of MSGLs on the southern flank of Perrier Trough. Furthermore, about $3 \mathrm{~km}$ north of the boundary of MSGL and to the east of the other basins, linear features connect a small basin $\sim 300 \mathrm{~m}$ in diameter with a similarly sized mound $1.6 \mathrm{~km}$ to its WNW (Fig. 5a).

We interpret the well-defined southern lateral boundary of MSGL in Perrier Trough as indicating the marginal shear zone position when the palaeo-ice stream reached its maximum width during the LGM. Similarly, the lateral limit of MSGL on the eastern flank of the AHT lies within a band that is no more than $3 \mathrm{~km}$ wide, indicating the approximate position of the shear zone at the margin of the palaeo-ice stream occupying this trough when it was at its widest. Such clear expressions of ice stream shear margin positions in bed morphology have proved elusive beneath the modern ice sheet, partly because the chaotic structure of shear zones causes scattering of ice-penetrating radar signals that is observed as "clutter" in survey data (Shabtaie and Bentley, 1987). The steep-sided basins in the area between the two troughs are similar to the holes of hill-hole pairs and scars resulting from detachment of sediment rafts observed on the northeastern part of the Amundsen Sea continental shelf (Klages et al., 2013, 2015, 2016). The small mound and basin in the Perrier Trough $3 \mathrm{~km}$ north of the boundary of MSGLs appear to be a clear example of a hill-hole pair. Such features are generally regarded as characteristic of erosion and deformation beneath dry-based ice cover (e.g. Ottesen et al., 2005; Evans et al., 2006). The mound to the northwest of one of the largest basins may represent a corresponding hill (Fig. 5a, c), although as its cross-sectional area is smaller than that of the adjacent hole it cannot contain all of the excavated sediment. The absence of mounds close to some of the other basins may be explained by their close proximity to the palaeo-ice stream confluence, as the excavated material would only need to have been transported a short distance into the path of one of the ice streams to be entrained by faster flow. Evidence of hill-hole pairs having been overridden and eroded by ice after their formation has previously been reported from the Norwegian continental shelf, where some hills are observed to have streamlined tails (Rise et al., 2016). The pristine form of the hill-hole pair within the Perrier Trough indicates that it must have formed after ice stream flow had stagnated.

A DTB profile runs across the bathymetric basin that lies closest to the confluence of the two troughs and, beneath thin, patchily distributed younger sediments, it shows an acoustically transparent layer up to $25 \mathrm{~ms}(\sim 20 \mathrm{~m})$ thick (Figs. 5a, 6). This layer has a minimum thickness of $<3 \mathrm{~m}$ beneath the southeastern edge of the basin floor, and it thickens progressively to the northwest across the basin. In places short segments of truncated, dipping reflectors can be seen beneath the strong reflector at the base of the acoustically transparent layer (Fig. 6). We interpret the acoustically transparent layer as consisting of Quaternary diamictons overlying an unconformity above mid-shelf basin sedimentary strata that are represented by the truncated, dipping reflectors. The reduced thickness of the acoustically transparent layer across the basin suggests that the "hole" was formed by erosion of Quaternary diamictons and that the older sedi- 

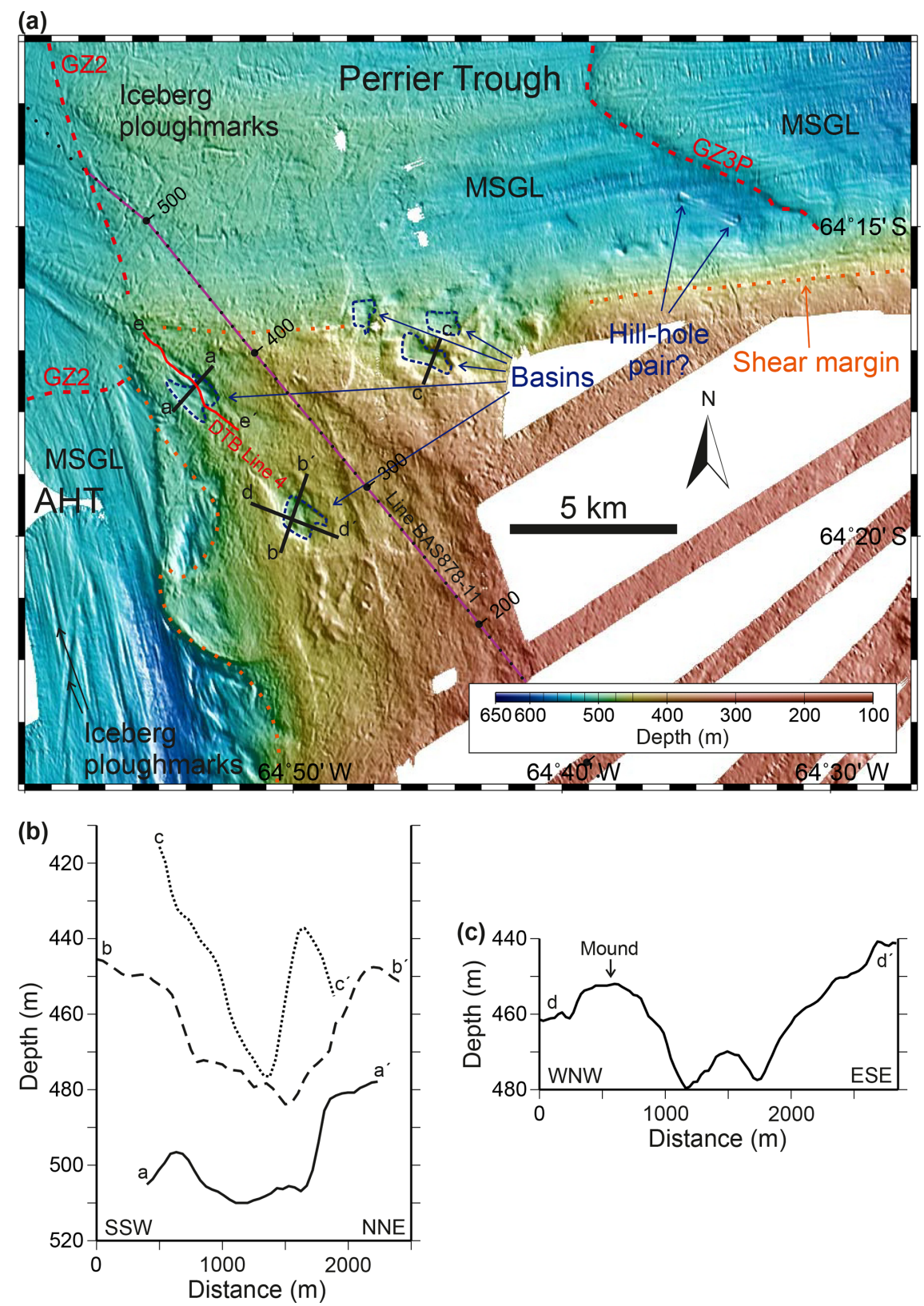

Figure 5. (a) Details of multibeam bathymetry over the confluence between Anvers-Hugo Trough and Perrier Trough, which joins it from the east. Grid-cell size $30 \mathrm{~m}$, displayed with shaded relief illumination from northeast. The black lines mark locations of topographic profiles in (b)-(c). The red line marks the location of the DTB profile in Fig. 6. The purple line marks the location of the MCS profile in Fig. 7, with small dots at intervals of 10 shots and larger dots and annotations at 100-shot intervals. Dark blue dashed lines outline selected boxshaped bathymetric basins. AHT, Anvers-Hugo Trough; MSGL, mega-scale glacial lineations; GZ2, GZ3P, interpreted former grounding zone positions marked by dashed red lines. The orange dotted line marks the lateral limit of MSGL, interpreted as the position of palaeo-ice stream shear margins. (b) Cross sections of box-shaped basins running approximately SW-NE (i.e. approximately transverse to the inferred palaeo-ice flow direction). (c) Cross section of one of the larger basins in an approximately NW-SE direction. Locations of profiles shown in (a).

mentary strata were unaffected during its formation. As mentioned above, such holes are generally regarded as characteristic of erosion beneath dry-based ice cover, and therefore the restriction of erosion to the Quaternary diamictons is consistent with the shear stress threshold for brittle failure in them likely being significantly lower than in the underlying consolidated strata (Evans et al., 2006). At the seabed near the foot of the steep southeast flank of the basin, a unit that is $180 \mathrm{~m}$ across and $7 \mathrm{~ms}(\sim 5.5 \mathrm{~m})$ thick containing southeastdipping reflectors is observed. We interpret this unit as a ro- 


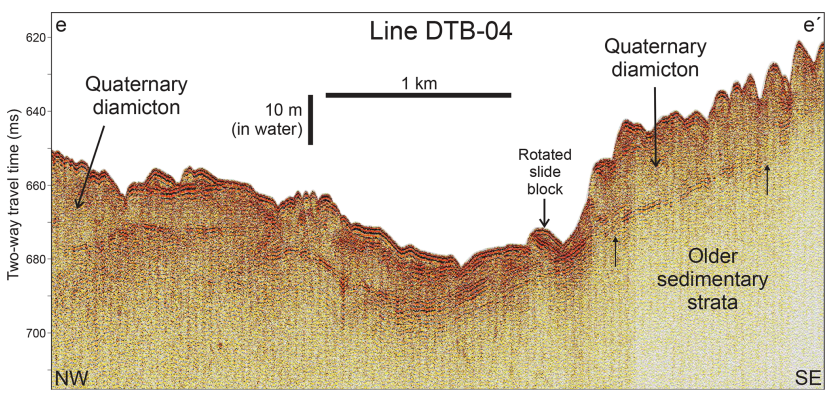

Figure 6. Part of DTB Line 4 across the step-sided basin that lies closest to the trough confluence. The profile shows an acoustically transparent layer of variable thickness, interpreted as Quaternary diamicton, overlying a strong reflector, interpreted as an unconformity above older sedimentary strata. Short segments of truncated, dipping reflectors, marked by upward-pointing small arrows, can be seen beneath the strong reflector at the base of the acoustically transparent layer. Two-way travel times have been corrected for the tow depth of the boomer so that they represent approximate times from the sea surface. Location of profile shown in Fig. 5a.

tated slide block that has originated from the flank of the hole after its excavation. The most prominent reflector within the block is most likely to be from the boundary between diamicton and postglacial sediment as observed to the NW of the basin (Fig. 6), in which case the displacement of the block did not occur until after a layer of postglacial sediments several metres in thickness had accumulated.

A MCS profile that runs obliquely across Perrier Trough and continues over the inter-trough area shows mid-shelf basin sedimentary strata underlying the seabed along the entire line (Figs. 5a, 7). As noted above, the oldest strata in this basin may be as old as Late Cretaceous, but most of the basin fill is likely of Tertiary age (Larter et al., 1997). The southern lateral limit of MSGL in Perrier Trough lies within $1 \mathrm{~km}$ of the position where a unit of younger strata with a distinct seismic facies character (labelled "later mid-shelf basin" in Fig. 7) pinches out, but is not coincident with this boundary.

\section{Discussion and conclusions}

The features described here suggest that subglacial water, likely supplied episodically from a subglacial lake in PD, played an important role in facilitating ice stream flow in the AHT during the last and probably several late Quaternary glacial periods, and likely modulated the flow velocity.

In the palaeo-ice stream confluence area (Fig. 5a) the close juxtaposition of MSGLs, which are characteristic of wetbased, fast ice flow (Stokes and Clark, 1999; King et al., 2009; Graham et al., 2009), with excavated basins (holes) that are characteristic of slow, dry-based ice flow (Ottesen et al., 2005; Evans et al., 2006), suggests that water availability was an important control on the lateral extent of the palaeoice streams. This interpretation is supported by a MCS profile

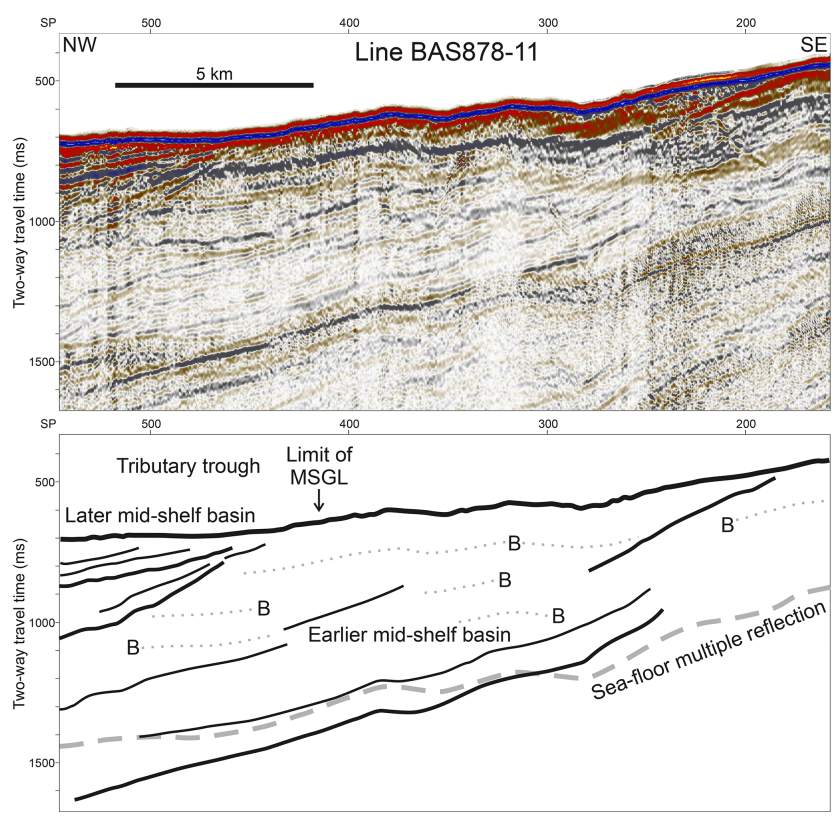

Figure 7. Part of MCS Line BAS878-11 and interpreted line drawing, showing the entire area of the confluence between AnversHugo Trough and a tributary trough is underlain by sedimentary strata, and that the lateral limit of MSGL in the tributary trough lies within $1 \mathrm{~km}$ of the position where a unit of younger strata with a distinct seismic facies character pinches out. An f-k demultiple process was used to suppress the sea-floor multiple reflection on this line. Dotted grey lines labelled B on the line drawing mark prominent bubble pulse reverberations following the sea-floor reflection. Location of profile shown in Fig. 5a.

that shows the palaeo-ice stream shear margin position on the south side of Perrier Trough does not coincide with a major geological boundary (Fig. 7). The MCS profile shows that the Perrier Trough palaeo-ice stream and the inter-stream area are both underlain by dipping sedimentary strata of likely Tertiary age. The position of the shear margin does, however, lie within $1 \mathrm{~km}$ of a second-order boundary between strata of different ages and with different seismic facies that may have had some influence on its position (Fig. 7). Unfortunately, available seismic profiles are too widely spaced to assess how closely the palaeo-shear margin follows this boundary.

The observation that a few of the holes, and one clear hillhole pair, span the boundary of, and cross-cut, MSGLs on the southern flank of Perrier Trough suggests inward ice stream shear margin migration during glacial recession. Lateral migration of shear margins was inferred in the area near the grounding on the modern Thwaites Glacier between 1996 and 2000 (Rignot et al., 2002), although a later study concluded that there had been no significant migration of the eastern shear margin of the glacier during the most recent 2 decades (MacGregor et al., 2013). On different parts of the northern shear margin of Whillans Ice Stream, migra- 
tion rates of up to $280 \mathrm{ma}^{-1}$ outwards and up to $170 \mathrm{ma}^{-1}$ inwards were measured over the decade to 1997 (Stearns et al., 2005). Ice-penetrating radar data across the northern margin of Kamb Ice Steam suggest abrupt inward migration of the margin $\sim 200$ years before complete stagnation flow, attributed to reduced lubrication (Catania et al., 2006). Reduction in basal water supply could occur due to depletion of upstream reservoirs (see Christoffersen et al., 2014), due to surface slope reduction leading to subglacial flow change/reversal, or due to ice thinning or decreasing flow rate and consequent reduction in pressure melting or strain heating. Alternatively, in the case of palaeo-ice streams on continental shelves, reduction in basal water supply could have resulted from total evacuation of subglacial lakes trapped during ice advance at the LGM. The recovery of tills older than $13 \mathrm{kacal}$ BP at the bases of sediment cores from PD indicates that the lake there was eventually evacuated (Barker and Camerlenghi 2002; Domack et al., 2001, 2006). However, water discharged from PD would not have supplied the bed of the palaeo-ice stream in Perrier Trough, so lake evacuation could only explain decreased water supply there if subglacial lakes were trapped in other deep basins upstream of the area studied.

The onset of MSGL in AHT coincides with the downstream termination of the northward-shoaling valleys. This spatial coincidence suggests that water delivered through the channels played a role in promoting streaming ice flow northward of this point. The upstream dip of $2^{\circ}$ along the steepest part of the channels (Fig. 2d) implies the minimum ice surface gradient required to produce a basal hydrological pressure gradient that would drive water northward along the valleys was only $0.2^{\circ}$, which is within the range of surface gradients on many modern ice streams (Horgan and Anandakrishnan, 2006). Water that flowed along the valleys may have been either incorporated into the till layer that the MSGLs formed in, thereby dilating it and facilitating shear deformation, or dissipated into a thin film that spread along the ice-sediment interface (see Ó Cofaigh et al., 2005a). The sudden appearance of MSGLs at this point also requires a source for the till itself, and the most obvious candidate is the underlying strata at the edge of the sedimentary basin (Fig. 3). Although these strata have never been sampled they are the most likely source of reworked Cretaceous radiolarians found in diamictons recovered by drilling on the outer shelf (Shipboard Scientific Party, 1999). Onset of MSGLs where ice flowed onto a bed consisting of older sedimentary strata has also been reported in other locations (e.g. Wellner et al., 2001, 2006; Graham et al., 2009). Erosion of material from underlying sedimentary strata by, or in the presence of, subglacial water flow presents a potential mechanism for generating a dilated basal till layer of the kind that has been shown to be present beneath some modern ice streams (e.g. Alley et al., 1986; Smith, 1997).

Subglacial lakes in deep inshore basins such as PD are likely to form during an ice sheet growth phase (Domack et al., 2006; Alley et al., 2006). In this case, episodes of water expulsion from PD may have accelerated ice flow and thus contributed to rapid advance of grounded ice with a low surface gradient across the shelf. Acceleration of ice flow by about $10 \%$ over 14 months was observed on Byrd Glacier following a drainage event from subglacial lakes $200 \mathrm{~km}$ upstream of the grounding line (Stearns et al., 2008), and subglacial meltwater drainage flux and routing is also known to influence flow rates of glaciers in Greenland (Sundal et al., 2011). The axis of AHT shallows steadily from $>600 \mathrm{~m}$ where MSGLs start on the middle shelf to $<440 \mathrm{~m}$ at the shelf edge (Vanneste and Larter, 1995), and grounding lines are potentially unstable on such upstreamdeepening beds (Weertman, 1974; Schoof, 2007; Katz and Worster, 2010). Therefore, if episodic subglacial water outbursts caused "surging" ice stream behaviour, as envisaged by Alley et al. (2006), they may also have resulted in fluctuations in grounding line positions.

Our interpretations are consistent with the hypothesis that subglacial lakes or areas of elevated geothermal heat flux play a critical role in the onset of many large ice streams (Bell, 2008). There are other deep, steep-sided inner shelf basins where subglacial lakes could have been trapped during glacial advance in the catchment areas of several other welldocumented Antarctic palaeo-ice streams. For example, there are several basins $>900 \mathrm{~m}$ deep in Marguerite Bay, which is part of the catchment of the Marguerite Trough palaeoice stream (Livingstone et al., 2013; Arndt et al., 2013), and there is a $>1100 \mathrm{~m}$ deep basin in Eltanin Bay at the head of the Belgica Trough palaeo-ice stream (Ó Cofaigh et al., 2005b; Graham et al., 2011; Arndt et al., 2013). In the Amundsen Sea embayment, there are $>1500 \mathrm{~m}$ deep inner shelf basins in the catchments of both the Pine IslandThwaites and Dotson-Getz palaeo-ice streams (Larter et al., 2009; Graham et al., 2009, 2016; Nitsche et al., 2013; Arndt et al., 2013; Witus et al., 2014), and it has been shown that at least one of those in the former area did indeed host a subglacial lake (Kuhn et al., 2017). Hence subglacial lakes at the onset of many continental shelf palaeo-ice streams may have facilitated their advance across the shelf during late Quaternary glacial periods. Furthermore, if the lakes persisted when the ice streams had advanced to the outer shelf, outbursts from them could have caused surge-like behaviour leading to fluctuations in grounding line positions on typical inward-deepening Antarctic continental shelf areas. Such behaviour of marine-based palaeo-ice streams on timescales of the order of centuries, as suggested by the simple model proposed by Alley et al. (2006), could explain the observation of cross-cutting MSGLs in several outer continental shelf areas (e.g. Ó Cofaigh et al., 2005a, b; Mosola and Anderson, 2006). The preservation of MSGLs from successive flow phases precludes erosion or deposition of more than a few metres of sediment between them, which is easier to envisage if the time separation between the flow phases is relatively small. The potential for such subglacial lake outbursts 
to recur at decadal to centennial intervals and to cause significant ice dynamic fluctuations means that there is a need to better understand the processes involved in order to better forecast the future behaviour of modern ice streams and the contribution they will make to sea level change.

Data availability. The multibeam bathymetry grid is available online from the UK Polar Data Centre (https://doi.org/10.5285/70905d9c-6dc0-421b-b20b-1e2dff97e802, Larter et al., 2019). The raw multibeam data and acoustic subbottom profiler data collected on cruise JR284, as well as the heritage seismic data, are available from the UK Polar Data Centre on request. Stacked MCS data from Line AMG845-03 are available from the Scientific Committee on Antarctic Research Seismic Data Library System (https://sdls.ogs.trieste.it/, last access: December 2018; SCAR, 2018).

Supplement. The supplement related to this article is available online at: https://doi.org/10.5194/tc-13-1583-2019-supplement.

Author contributions. RDL conceived the idea for the study and together with C-DH, JAS, JAD, KAH, and AGCG developed the research plan for cruise JR284. RDL together with KAH, C-DH, and JAS wrote the paper. RDL, KAH, AJT, CLB, C-DH, JAS, and MC collected the multibeam bathymetry and acoustic sub-bottom profile data on cruise JR284. JDK, ZAR, GK, AGCG, and JAD participated in discussions with the aforementioned authors on interpretation of the data and their implications for subglacial hydrological systems. All authors commented on the paper and provided input to its final version.

Competing interests. The authors declare that they have no conflict of interest.

Acknowledgements. We thank the captain, officers, and crew on RRS James Clark Ross cruise JR284, and Elanor Gowland and Ove Meisel, who assisted with data collection. We also thank the captain, hydrographers, officers, and crew who sailed on HMS Protector during the 2015-16 and 2016-17 Antarctic seasons, from which additional data were incorporated. Heritage data collected on RVIB Nathaniel B. Palmer were obtained from the Marine Geoscience Data System (http://www.marine-geo.org/index.php, last access: December 2018). The MCS data on Line BAS878-11 were processed by Alex Cunningham, and Christian dos Santos Ferreira provided valuable help and advice in using MB-System to suppress some artefacts. Participation of KAH, CLB, and MC on cruise JR284 was funded by Natural Environment Research Council Collaborative Gearing Scheme awards. We thank the anonymous reviewers for helpful reviews that improved the paper.
Financial support. This research has been supported by the British Antarctic Survey, Natural Environment Research Council, Polar Science for Planet Earth programme.

Review statement. This paper was edited by Christian Hauck and reviewed by two anonymous referees.

\section{References}

Alley, R. B., Blankenship, D. D., Bentley, C. R., and Rooney, S. T.: Deformation of till beneath ice stream B, West Antarctica, Nature, 322, 57-59, 1986.

Alley, R. B., Dupont, T. K., Parizek, B. R., Anandakrishnan, S., Lawson, D. E., Larson, G. J., and Evenson, E. B.: Outburst flooding and the initiation of ice-stream surges in response to climatic cooling: A hypothesis, Geomorphology, 75, 76-89, 2006.

Anderson, J.: Processed Multibeam Sonar Data (version 2) near the Antarctic Peninsula acquired during Nathaniel B. Palmer expedition NBP0201 (2002), Interdisciplinary Earth Data Alliance (IEDA), https://doi.org/10.1594/IEDA/100309, 2005.

Arndt, J. E., Schenke, H. W., Jakobsson, M., Nitsche, F. O., Buys, G., Goleby, B., Rebesco, M., Bohoyo, F., Hong, J., Black, J., Greku, R., Udintsev, G., Barrios, F., Reynoso-Peralta, W., Taisei, M., and Wigley, R.: The International Bathymetric Chart of the Southern Ocean (IBCSO) Version 1.0 - A new bathymetric compilation covering circum-Antarctic waters, Geophys. Res. Lett., 40, 3111-3117, https://doi.org/10.1002/grl.50413, 2013.

Barker, P. F. and Camerlenghi, A.: Glacial history of the Antarctic Peninsula from Pacific margin sediments, in: Antarctic Glacial History and Sea-Level Change, edited by: Barker, P. F., Camerlenghi, A., Acton, G. D., and Ramsay, A. T. S., Proceedings of the Ocean Drilling Program, Scientific Results, Vol. 178, 1-40, https://www-odp.tamu.edu/publications/ 178_SR/synth/synth.htm (last access: December 2018), 2002.

Bart, P. J. and Iwai, M.: The overdeepening hypothesis: How erosional modification of the marine-scape during the early Pliocene altered glacial dynamics on the Antarctic Peninsula's Pacific margin, Palaeogeogr. Palaeoclimatol. Palaeoecol. 335-336, 4251, https://doi.org/10.1016/j.palaeo.2011.06.010, 2012.

Batchelor, C. L. and Dowdeswell, J. A.: Ice-sheet grounding-zone wedges (GZWs) on high-latitude continental margins, Mar. Geol., 363, 65-92, https://doi.org/10.1016/j.margeo.2015.02.001, 2015.

Bell, R. E.: The role of subglacial water in ice-sheet mass balance, Nat. Geosci., 1, 297-304, https://doi.org/10.1038/ngeo186, 2008.

Bell, R. E., Studinger, M., Shuman, C. A., Fahnestock, M. A., and Joughin, I.: Large subglacial lakes in East Antarctica at the onset of fast-flowing ice streams, Nature, 445, 904-907, https://doi.org/10.1038/nature05554, 2007.

Caress, D. W. and Chayes, D. N.: Improved processing of Hydrosweep DS multibeam data on the R/V Maurice Ewing, Mar. Geophys. Res., 18, 631-650, 1996.

Caress, D. W., Chayes, D. N., and dos Santos Ferreira, C.: MBSystem: Mapping the Seafloor, available at: https://www.mbari org/products/research-software/mb-system (last access: December 2018), 2018. 
Catania, G. A., Scambos, T. A., Conway, H., and Raymond, C. H.: Sequential stagnation of Kamb Ice Stream, West Antarctica, Geophys. Res. Lett., 33, L14502, https://doi.org/10.1029/2006GL026430, 2006.

Christianson, K., Jacobel, R. W., Horgan, H. J., Anandakrishnan, S., and Alley, R. B.: Subglacial Lake Whillans - Ice-penetrating radar and GPS observations of a shallow active reservoir beneath a West Antarctic ice stream, Earth Planet. Sci. Lett., 331-332, 237-245, https://doi.org/10.1016/j.epsl.2012.03.013, 2012.

Christianson, K., Peters, L. E., Alley, R. B., Ananadakrishnan, S., Jacobel, R. W., Riverman, K. L., Muto, A., and Keisling, B. A.: Dilatant till facilitates ice-stream flow in northeast Greenland, Earth Planet. Sci. Lett., 401, 57-69, https://doi.org/10.1016/j.epsl.2014.05.060, 2014.

Christoffersen, P., Bougamont, M., Carter, S. P., Fricker, H. A., and Tulaczyk, S.: Significant groundwater contribution to Antarctic ice streams hydrologic budget, Geophys. Res. Lett., 41, 2003 2010, https://doi.org/10.1002/2014GL059250, 2014.

Domack, E.: Processed Multibeam Sonar Data (version 2) near the Antarctic Peninsula acquired during Nathaniel B. Palmer expedition NBP0107 (2001), Interdisciplinary Earth Data Alliance (IEDA), https://doi.org/10.1594/IEDA/100307, 2005.

Domack, E., Leventer, A., Dunbar, R., Taylor, F., Brachfeld, S., and Sjunneskog, C.: Chronology of the Palmer Deep site, Antarctic Peninsula: a Holocene palaeoenvironmental reference for the circum-Antarctic, The Holocene, 11, 1-9, https://doi.org/10.1191/095968301673881493, 2001.

Domack, E. W., Amblàs, D., Gilbert, R., Brachfeld, S., Camerlenghi, A., Rebesco, M., Canals, M., and Urgeles, R.: Subglacial morphology and glacial evolution of the Palmer deep outlet system, Antarctic Peninsula, Geomorphology, 75, 125-142, https://doi.org/10.1016/j.geomorph.2004.06.013, 2006.

Dowdeswell, J. A., Canals, M., Jakobsson, M., Todd, B. J., Dowdeswell, E. K., and Hogan, K. A.: Introdcution: an atlas of submarine glacial landforms, in: Atlas of Submarine Glacial Landforms: Modern, Quaternary and Ancient, edited by: Dowdeswell, J. A., Canals, M., Jakobsson, M., Todd, B. J., Dowdeswell, E. K., and Hogan, K. A., Memoirs, Geological Society, London, Vol. 46, 3-14, https://doi.org/10.1144/M46.171, 2016.

Dreimanis, A.: Water-eroded crescentic scours and furrows associated with subglacial flutes at Breidamerkurjökull, Iceland, Boreas, 22, 110-112, https://doi.org/10.1111/j.15023885.1993.tb00170.x, 1993.

Evans, D. J. A., Phillips, E. R., Hiemstra, J. F., and Auton, C. A.: Subglacial till: formation, sedimentary characteristics and classification, Earth-Sci. Rev., 78, 115-176, https://doi.org/10.1016/j.earscirev.2006.04.001, 2006.

Fahnestock, M., Abdalati, W., Joughin, I., Brozena, J., and Gogineni, P.: High geothermal heat flow, basal melt, and the origin of rapid ice flow in central Greenland, Science, 294, 2338-2342, 2001.

Fricker, H. A., Scambos, T., Bindschadler, R., and Padman, L.: An active subglacial water system in West Antarctica mapped from space, Science, 315, 1544-1548, 2007.

Graham, A. G. C. and Hogan, K. A.: Crescentic scours on palaeoice stream beds, in: Atlas of Submarine Glacial Landforms: Modern, Quaternary and Ancient, edited by: Dowdeswell, J. A., Canals, M., Jakobsson, M., Todd, B. J., Dowdeswell, E. K., and
Hogan, K. A., Memoirs, Geological Society, London, Vol. 46, 221-222, https://doi.org/10.1144/M46.166, 2016.

Graham, A. G. C., Larter, R. D., Gohl, K., Hillenbrand, C.-D., Smith, J. A., and Kuhn, G.: Bedform signature of a West Antarctic palaeo-ice stream reveals a multi-temporal record of flow and substrate control, Quaternary Sci. Rev., 28, 2774-2793, https://doi.org/10.1016/j.quascirev.2009.07.003, 2009.

Graham, A. G. C., Nitsche, F. O., and Larter, R. D.: An improved bathymetry compilation for the Bellingshausen Sea, Antarctica, to inform ice-sheet and ocean models, The Cryosphere, 5, 95106, https://doi.org/10.5194/tc-5-95-2011, 2011.

Graham, A. G. C., Jakobsson, M., Nitsche, F. O., Larter, R. D., Anderson, J. B., Hillenbrand, C.-D., Gohl, K., Klages, J. P., Smith, J. A., and Jenkins, A.: Submarine glacial-landform distribution across the West Antarctic margin, from grounding line to slope: the Pine Island-Thwaites ice-stream system, in: Atlas of Submarine Glacial Landforms: Modern, Quaternary and Ancient, edited by: Dowdeswell, J. A., Canals, M., Jakobsson, M., Todd, B. J., Dowdeswell, E. K., and Hogan, K. A., Memoirs, Geological Society, London, Vol. 46, 493-500, https://doi.org/10.1144/M46.173, 2016.

Hernández-Molina, F. J., Larter, R. D., and Maldonado, A.: Neogene to Quaternary Stratigraphic Evolution of the Antarctic Peninsula, Pacific Margin offshore of Adelaide Island: transitions from a non-glacial, through glacially-influenced to a fully glacial state, Global Planet. Change, 156, 80-111, https://doi.org/10.1016/j.gloplacha.2017.07.002, 2017.

Heroy, D. C. and Anderson, J. B.: Ice-sheet extent of the Antarctic Peninsula region during the Last Glacial Maximum (LGM) - Insights from glacial geomorphology, Geol. Soc. Am. Bull., 117, 1497-1512, 2005.

Horgan, H. J. and Anandakrishnan, S.: Static grounding lines and dynamic ice streams: Evidence from the Siple Coast, West Antarctica, Geophys. Res. Lett. 33, L18502, https://doi.org/10.1029/2006GL027091, 2006.

Katz, R. F. and Worster, M. G.: Stability of ice-sheet grounding lines, Proc. Royal Soc. A, 466, 1597-1620, https://doi.org/10.1098/rspa.2009.0434, 2010.

King, E. C., Hindmarsh, R. C. A., and Stokes, C. R.: Formation of mega-scale glacial lineations observed beneath a West Antarctic ice stream, Nat. Geosci., 2, 585-588, https://doi.org/10.1038/NGEO581, 2009.

Kirkham, J. D., Hogan, K. A., Larter, R. D., Arnold, N. S., Nitsche, F. O., Golledge, N. R., and Dowdeswell, J. A.: Past water flow beneath Pine Island and Thwaites glaciers, West Antarctica, The Cryosphere Discuss., https://doi.org/10.5194/tc-2019-67, in review, 2019.

Klages, J. P., Kuhn, G., Hillenbrand, C.-D., Graham, A. G. C., Smith, J. A., Larter, R. D., and Gohl, K.: First geomorphological record and glacial history of an inter-ice stream ridge on the West Antarctic continental shelf, Quaternary Sci. Rev., 61, 4761, https://doi.org/10.1016/j.quascirev.2012.11.007, 2013.

Klages, J. P., Kuhn, G., Graham, A. G. C., Hillenbrand, C.-D., Smith, J. A., Nitsche, F. O., Larter, R. D., and Gohl, K.: Palaeo-ice stream pathways and retreat style in the easternmost Amundsen Sea Embayment, West Antarctica, revealed by combined multibeam bathymetric and seismic data, Geomorphology, 245, 207-222, https://doi.org/10.1016/j.geomorph.2015.05.020, 2015. 
Klages, J. P., Kuhn, G., Hillenbrand, C.-D., Graham, A. G. C., Smith, J. A., Larter, R. D., and Gohl, K.: A glacial landform assemblage from an inter-ice stream setting in the eastern Amundsen Sea Embayment, West Antarctica, in: Atlas of Submarine Glacial Landforms: Modern, Quaternary and Ancient, edited by: Dowdeswell, J. A., Canals, M., Jakobsson, M., Todd, B. J., Dowdeswell, E. K., and Hogan, K. A., Memoirs, Geological Society, London, Vol. 46, 349-352, https://doi.org/10.1144/M46.147, 2016.

Kuhn, G., Hillenbrand, C.-D., Kasten, S., Smith, J. A., Nitsche, F. O., Frederichs, T., Wiers, S., Ehrmann, W., Klages, J. P., and Mogollón, J. M.: Evidence for a palaeo-subglacial lake on the Antarctic continental shelf, Nat. Commun., 8, 15591, https://doi.org/10.1038/ncomms15591, 2017.

Larter, R. D. and Cunningham, A. P.: The depositional pattern and distribution of glacial-interglacial sequences on the Antarctic Peninsula Pacific margin, Mar. Geol., 109, 203-219, 1993.

Larter, R. D. and Vanneste, L. E.: Relict subglacial deltas on the Antarctic Peninsula outer shelf, Geology, 23, 33-36, 1995.

Larter, R. D., Rebesco, M. Vanneste, L. E., Gambôa, L. A. P., and Barker, P. F.: Cenozoic tectonic, sedimentary and glacial history of the continental shelf west of Graham Land, Antarctic Peninsula, in: Geology and Seismic Stratigraphy of the Antarctic Margin, 2, edited by: Barker, P. F. and Cooper, A. K., Antarctic Research Series, American Geophysical Union, Washington, DC, Vol. 71, 1-27, 1997.

Larter, R. D., Graham, A. G. C., Gohl, K., Kuhn, G., Hillenbrand, C.-D., Smith, J. A., Deen, T. J., Livermore, R. A., and Schenke, H.-W.: Subglacial bedforms reveal complex basal regime in a zone of paleo-ice stream convergence, Amundsen Sea Embayment, West Antarctica, Geology, 37, 411-414, https://doi.org/10.1130/G25505A.1, 2009.

Larter, R. D., Hogan, K. A., Hillenbrand, C.-D., Smith, J. A., Batchelor, C. L., Cartigny, M., Tate, A. J., Kirkham, J. D., Roseby, Z. A., Graham, A. G. C., and Dowdeswell, J. A.: A bathymetric compilation over Anvers-Hugo Trough, Perrier Trough and Palmer Deep, 1990-2017, UK Polar Data Centre, doi10.5285/70905d9c-6dc0-421b-b20b, 2019.

Lavoie, C., Domack, E. W., Pettit, E. C., Scambos, T. A., Larter, R. D., Schenke, H.-W., Yoo, K. C., Gutt, J., Wellner, J., Canals, M., Anderson, J. B., and Amblas, D.: Configuration of the Northern Antarctic Peninsula Ice Sheet at LGM based on a new synthesis of seabed imagery, The Cryosphere, 9, 613-629, https://doi.org/10.5194/tc-9-613-2015, 2015.

Leat, P. T., Scarrow, J. H., and Millar, I. L.: On the Antarctic Peninsula batholiths, Geol. Mag., 132, 399-412, 1995.

Lewis, A. R., Marchant, D. R., Kowalewski, D. E., Baldwin, S. L., and Webb, L. E.: The age and origin of the Labyrinth, western Dry Valleys, Antarctica: Evidence for extensive middle Miocene subglacial floods and freshwater discharge to the Southern Ocean, Geology, 34, 513-516, https://doi.org/10.1130/G22145.1, 2006.

Livingstone, S. J., Ó Cofaigh C., Stokes, C. R., Hillenbrand, C.-D., Vieli, A., and Jamieson, S. S. R.: Glacial geomorphology of Marguerite Bay Palaeo-Ice stream, western Antarctic Peninsula, J. Maps, 9, 558-572, https://doi.org/10.1080/17445647.2013.829411, 2013.
Lowe, A. L. and Anderson, J. B.: Evidence for abundant subglacial meltwater beneath the paleo-ice sheet in Pine Island Bay, Antarctica, J. Glaciol., 49, 125-138, 2003.

MacGregor, J. A., Catania, G. A., Conway, H., Schroeder, D. M., Joughin, I., Young, D. A., Kempf, S. D., and Blankenship, D. D.: Weak bed control of the eastern shear margin of Thwaites Glacier, West Antarctica, J. Glaciol., 59, 900-912, https://doi.org/10.3189/2013JoG13J050, 2013.

Mosola, A. B. and Anderson, J. B.: Expansion and rapid retreat of the West Antarctic Ice Sheet in eastern Ross Sea: possible consequence of over-extended ice streams?, Quaternart Sci. Rev., 25, 2177-2196, https://doi.org/10.1016/j.quascirev.2005.12.013, 2006.

Nitsche, F. O., Gohl, K., Larter, R. D., Hillenbrand, C.-D., Kuhn, G., Smith, J. A., Jacobs, S., Anderson, J. B., and Jakobsson, M.: Paleo ice flow and subglacial meltwater dynamics in Pine Island Bay, West Antarctica, The Cryosphere, 7, 249-262, https://doi.org/10.5194/tc-7-249-2013, 2013.

Ó Cofaigh, C., Pudsey, C. J., Dowdeswell, J. A., and Morris, P.: Evolution of subglacial bedforms along a paleo-ice stream, Antarctic Peninsula continental shelf, Geophys. Res. Lett., 29, 1199, https://doi.org/10.1029/2001GL014488, 2002.

Ó Cofaigh, C., Dowdeswell, J. A., Allen, C. S., Hiemstra, J., Pudsey, C. J., Evans, J., and Evans, D. J. A.: Flow dynamics and till genesis associated with a marine-based Antarctic palaeo-ice stream, Quaternary Sci. Rev., 24, 709-740, https://doi.org/10.1016/j.quascirev.2004.10.006, $2005 \mathrm{a}$.

Ó Cofaigh, C., Larter, R. D., Dowdeswell, J. A., Hillenbrand, C.-D., Pudsey, C. J., Evans, J., and Morris, P.: Flow of the West Antarctic Ice Sheet on the continental margin of the Bellingshausen Sea at the Last Glacial Maximum, J. Geophys. Res., 110, B11103, https://doi.org/10.1029/2005JB003619, 2005 b.

Ó Cofaigh, C., Dowdeswell, J. A., Evans, J., and Larter, R. D.: Geological constraints on Antarctic palaeo-icestream retreat, Earth Surf. Proc. Landf., 33, 513-525, https://doi.org/10.1002/esp.1669, 2008.

Ó Cofaigh, C., Davies, B. J., Livingstone, S. J., Smith, J. A., Johnson, J. S., Hocking, E. P., Hodgson, D. A., Anderson, J. B., Bentley, M. J., Canals, M., Domack, E., Dowdeswell, J. A., Evans, J., Glasser, N. F., Hillenbrand, C.-D., Larter, R. D., Roberts, S. J., and Simms, A. R.: Reconstruction of ice-sheet changes in the Antarctic Peninsula since the Last Glacial Maximum, Quaternary Sci. Rev., 100, 87-110, https://doi.org/10.1016/j.quascirev.2014.06.023, 2014.

Ottesen, D., Dowdeswell, J. A., and Rise, L.: Submarine landforms and the reconstruction of fast-flowing ice streams within a large Quaternary ice sheet: the 2500-km long Norwegian Svalbard margin $\left(57^{\circ}\right.$ to $\left.80^{\circ} \mathrm{N}\right)$, Geol. Soc. Am. Bull., 117, 1033-1050, https://doi.org/10.1130/B25577.1, 2005.

Pudsey, C. J., Barker, P. F., and Larter, R. D.: Ice sheet retreat from the Antarctic Peninsula shelf, Continental Shelf Res., 14, 16471675, 1994.

Rebesco, M., Camerlenghi, A., DeSantis, L., Domack, E. W., and Kirby, M.: Seismic stratigraphy of Palmer Deep: a fault-bounded late Quaternary sediment trap on the inner continental shelf, Antarctic Peninsula margin, Mar. Geol., 151, 89-110, 1998.

Reinardy, B. I., Larter, R. D., Hillenbrand, C.-D., Murray, T., Hiemstra, J. F., and Booth, A. D.: Streaming flow of an Antarctic Peninsula palaeo-ice stream, both by basal slid- 
ing and deformation of substrate, J. Glaciol., 57, 596-608, https://doi.org/10.3189/002214311797409758, 2011.

Rignot, E., Vaughan, D. G., Schmeltz, M., Dupont, T., and MacAyeal, D.: Acceleration of Pine Island and Thwaites Glaciers, West Antarctica, Ann. Glaciol., 34, 189-194, 2002.

Rise, L., Bellec, L. V., Ottesen, D., Bøe, R., and Thorsnes, T.: Hill-hole pairs on the Norwegian continental shelf, in: Atlas of Submarine Glacial Landforms: Modern, Quaternary and Ancient, edited by: Dowdeswell, J. A., Canals, M., Jakobsson, M., Todd, B. J., Dowdeswell, E. K., and Hogan, K. A., Memoirs, Geological Society, London, Vol. 46, 203-204, https://doi.org/10.1144/M46.42, 2016.

SCAR: Antarctic Seismic Data Library System (SDLS), available at: https://sdls.ogs.trieste.it/, last access: December 2018.

Schoof, C.: Ice sheet grounding line dynamics: Steady states, stability, and hysteresis, J. Geophys. Res., 112, F03S28, https://doi.org/10.1029/2006JF000664, 2007.

Shabtaie, S. and Bentley, C. R.: West Antarctic ice streams draining into the Ross Ice Shelf: configuration and mass balance, J. Geophys. Res., 92, 1311-1336, 1987.

Shipboard Scientific Party: Shelf Transect (Sites 1100, 1102, and 1103), in: Proc. ODP, Init. Repts., 178, edited by: Barker, P. F., Camerlenghi, A., Acton, G. D., et al., 183, available at: http://www-odp.tamu.edu/publications/178_IR/ VOLUME/CHAPTERS/CHAP_09.PDF (last access: 23 April 2019), 1999.

Siegfried, M. R., Fricker, H. A., Carter, S. P., and Tulczyk, S.: Episodic ice velocity fluctuations triggered by a subglacial flood in West Antarctica, Geophys. Res. Lett., 43, 2640-2648, https://doi.org/10.1002/2016GL067758, 2016.

Smith, A. M.: Basal conditions on Rutford Ice Stream, West Antarctica, from seismic observations, J. Geophys. Res., 102, 543-552, 1997.

Smith, J. A., Hillenbrand, C.-D., Larter, R. D., Graham, A. G. C., and Kuhn, G.: The sediment infill of subglacial meltwater channels on the West Antarctic continental shelf, Quaternary Res., 71, 190-200, https://doi.org/10.1016/j.yqres.2008.11.005, 2009.

Stearns, L. A., Jezek, K. C., and Van der Veen, C. J.: Decadal-scale variations in ice flow along Whillans Ice Stream and its tributaries, West Antarctica, J. Glaciol., 51, 147-157, 2005.

Stearns, L. A., Smith, B. E., and Hamilton, G. S.: Increased flow speed on a large East Antarctic outlet glacier caused by subglacial floods, Nat. Geosci., 1, 827-831, https://doi.org/10.1038/ngeo356, 2008.
Stokes, C. R. and Clark, C. D.: Geomorphological criteria for identifying Pleistocene ice streams, Ann. Glaciol., 28, 67-75, 1999.

Storey, B. C. and Garrett, S. W.: Crustal growth of the Antarctic Peninsula by accretion, magmatism and extension, Geol. Mag., 122, 5-14, 1985.

Studinger, M., Bell, R. E., and Tikku, A. A.: Estimating the depth and shape of subglacial Lake Vostok's water cavity from aerogravity data, Geophys. Res. Lett., 31, L12401, https://doi.org/10.1029/2004GL019801, 2004.

Sundal, A. V., Shepherd, A., Nienow, P., Hanna, E., Palmer, S., and Huybrechts, P.: Melt-induced speed-up of Greenland ice sheet offset by efficient subglacial drainage, Nature, 469, 521-524, https://doi.org/10.1038/nature09740, 2011.

Vanneste, L. E and Larter, R. D.: Deep-tow boomer survey on the Antarctic Peninsula Pacific margin: An investigation of the morphology and acoustic characteristics of late Quaternary sedimentary deposits on the outer continental shelf and upper slope, in: Geology and Seismic Stratigraphy of the Antarctic Margin, edited by: Cooper, A. K., Barker, P. F., and Brancolini, G., Antarctic Research Series, American Geophysical Union, Washington, DC, Vol. 68, 97-121, 1995.

Weertman, J.: Stability of the junction of an ice sheet and an ice shelf, J. Glaciol., 13, 3-11, 1974.

Wellner, J. S., Lowe, A. L., Shipp, S. S., and Anderson, J. B.: Distribution of glacial geomorphic features on the Antarctic continental shelf and correlation with substrate: implications for ice behaviour, J. Glaciol., 47, 397-411, 2001.

Wellner, J. S., Heroy, D. C., and Anderson, J. B.: The death mask of the antarctic ice sheet: Comparison of glacial geomorphic features across the continental shelf, Geomorphology, 75, 157-171, https://doi.org/10.1016/j.geomorph.2005.05.015, 2006.

Witus, A. E., Branecky, C. M., Anderson, J. B., Szczuciński, W., Schroeder, D. M., Blankenship, D. D., and Jakobsson, M.: Meltwater intensive glacial retreat in polar environments and investigation of associated sediments: example from Pine Island Bay, West Antarctica, Quaternary Sci. Rev., 85, 99-118, https://doi.org/10.1016/j.quascirev.2013.11.021, 2014.

Woodward, J., Smith, A. M., Ross, N., Thoma, M., Corr, H. F. J., King, E. C., King, M. A., Grosfeld, K., Tranter, M., and Siegert, M. J.: Location for direct access to subglacial Lake Ellsworth: An assessment of geophysical data and modelling, Geophys. Res. Lett., 37, L11501, https://doi.org/10.1029/2010GL042884, 2010. 